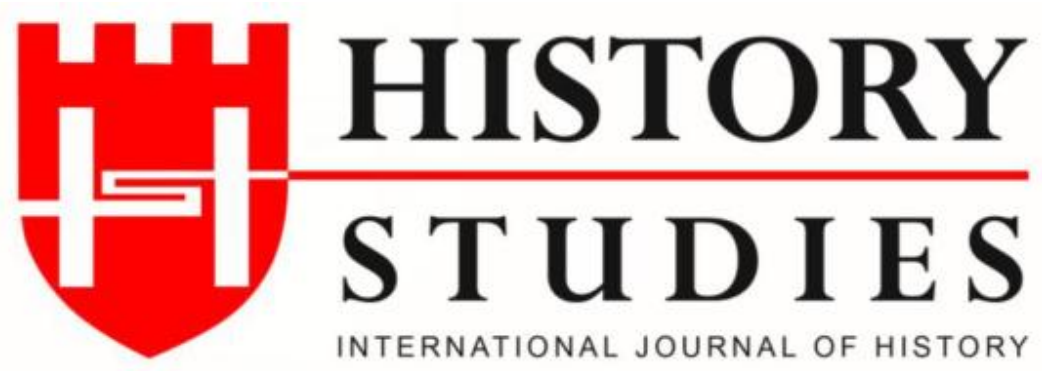

ISSN: 13094173 (Online) 1309 - 4688 (Print)

Volume 10 Issue 10, A Tribute to Prof. Dr. Yilmaz KURT, p. 251-266, December 2018

DOI Number: 10.9737/hist.2018.701

\title{
Birinci Dünya Savaşında ve Sonrasında Milliyetçi ve Şarkiyatçı Söylemlerde Türk Kadını ${ }^{1}$
}

Turkish Woman in Nationalist and Orientalist Discourses During and After WWI

\author{
Doç. Dr. Türkmen TÖRELİ - Dr. Füsun ÇOBAN DÖŞKAYA \\ (ORID: 0000-0002-7486-523X / 0000-0001-8121-4139) \\ Dokuz Eylül Üniversitesi- İzmir
}

\begin{abstract}
Öz: Kendilerini "öteki" yoluyla tanıtma ve tanıma çabası içerisinde olan şarkiyatçılar, sıklıkla kadınların temsiline odaklanmış, anlatılarında cinsiyetlendirilmiş bir mekân olarak harem ve kafesli pencerelerin gerisinde hayattan kopuk olarak yaşayan, korunmaya muhtaç, aciz doğulu kadını betimlemişlerdir. Şarkiyatçıların edilgen olan ve "Türk Kadınları" diye genelde çoğul olarak kullanılan anlatımları, milliyetçi söylem içerisinde etkin olan ve kitleler önünde konuşabilen bir bireye dönüşür. Milliyetçi söylemde Türk kadını savaşa katkl veren "ulusun annesi" haline gelir ve kadın olarak temsil edilen vatan gibi o da korunmalıdir.
\end{abstract}

Bu çalışmada, Birinci Dünya Savaşı ve sonrasında Türk kadını algısı, şarkiyatçı ve milliyetçi söylem içerisinde incelenip karşılaştırılacak, savaş zamanı Türk kadını anlatılarından örnekler verilecektir. Çalışmada amaçlanan, şarkiyatçı söylem ile milliyetçi söylemin Türk kadını betimlemeleri bağlamında karşılaştırılmasıyla her iki dil kullanımında da kadının bir araç olarak kullanıldı̆̆ını göstermektir. ${ }^{2}$

Anahtar Kelimeler: Birinci Dünya Savaşı, Türk Kadını, Milliyetçi Söylem, Şarkiyatçı Söylem, Kadınlar Dünyası Dergisi

\begin{abstract}
Orientalists who are struggling to identify and recognize themselves through the "other" have often focused on women's representation, describing women in need of protection, incapable of living in a state of disarray behind harem and caged windows as gendered spaces. Orientalists' passive and often plural narrative of "Turkish Women," turns into an individual who is active and who can speak in front of masses in nationalist discourse. In the nationalist discourse, the Turkish woman becomes a "mother of the nation" who contributes to the war and therefore must be protected like the homeland represented as a woman.

In this study, the perception of Turkish women during and after World War I will be examined and compared within orientalist, and nationalist discourses and examples will be given from the Turkish women's wartime narratives. By comparing the orientalist discourse and the nationalist discourse within the context of the representation of Turkish women; the study aims to show that women are used as a tool in both language usages.
\end{abstract}

Keywords: World War I, Turkish Woman, Nationalist Discourse, Orientalist Discourse, The Magazine of Women's World

\footnotetext{
${ }^{1}$ Bu çalışmanın bazı bölümleri 16-18 Ekim 2014 tarihinde İzmir Dokuz Eylül Üniversitesi'nde gerçekleștirilen II. Uluslararası Tarih Sempozyumu'nda "Kadın ve Savaş: Birinci Dünya Savaşında Milliyetçi ve Şarkiyatçı Söylemlerde Türk Kadını İmgeleri” başlı̆̆ıyla sunulmuştur.

2 Çalışmada kullanılan "Türk Kadını" ifadesi Şarkiyatçı metinlerde de olduğu üzere, sadece Müslüman kadınları kapsamamaktadır.
} 


\section{Giriş}

$\mathrm{Bu}$ çalışmada şarkiyatçı ve milliyetçi dil kullanımlarında Türk kadını temsilleri incelenmekte ve toplumda var olan iktidar eşitsizlikleri, iktidar ilişkilerini yansıtan ve yeniden üreten mekân bağlamında, şarkiyatçı söylemde "harem", milliyetçi söylemde "cephe" kavramları üzerinden irdelenmektedir. "Türkiye'de kadınlar üzerine söylemin dönüşümünde kilit noktalar, Osmanlı İmparatorluğu'ndan Türkiye Cumhuriyeti'ne geçişteki can alıcı yol ayrımlarına denk geldiğinden" ${ }^{3}$ ve bu yıllarda yaşanan savaşlar Türk kadın kimliğinin oluşmasında önemli bir rol oynadığından, çalışmada Birinci Dünya Savaşı ve İstiklal Savaşı (1914-1923) yılları incelenmektedir. Cumhuriyet dönemi Türk kadınının geldiği nokta, milli mücadele ruhunun başladığ çalışma içerisinde araştırılmaktadır.

Ülkemizde Osmanlı dönemi Türk kadınını kapsamlı bir şekilde ele alan çalışmalar ${ }^{4}$ kısıtlı sayıda olmakla beraber bu alanda yapılan çalışmalar günümüzde artış göstermektedir.

\footnotetext{
${ }^{3}$ Deniz Kandiyoti, Cariyeler, Bacılar, Yurttaşlar: Kimlikler ve Toplumsal Dönüşümler, 2. Baskı, Metis Yayınları, İstanbul 2007, s. 146-147.

${ }^{4}$ Osmanlı kadını konusunda ülkemizde yapılmış olan çalışmaların bir kısmı için bkz.: Şefika Kurnaz, Yenileşme Sürecinde Türk Kadını: 1839-1923, Ötüken Yayınları, İstanbul 2011; Şefika Kurnaz, Cumhuriyet Öncesinde Türk Kadını (1839-1923), 2. Baskı, T.C. Başbakanlık Aile Araştırma Kurumu Başkanlığı Yayınları, Ankara 1991; Şefika Kurnaz, II. Meşrutiyet Döneminde Türk Kadını, M.E.B. Yayınları, İstanbul 1996; Fatma Büyükkarcı Yılmaz, ve Tülay Gençtürk Demircioğlu (eds.) Kadınlar Dünyası 1.-50. Sayılar (Yeni Harflerle) (1913-1921). Kadın Eserleri Kütüphanesi ve Bilgi Merkezi Vakf1, İstanbul 2009; Tülay Gençtürk Demircioğlu ve Fatma Büyükkarcı Yılmaz (eds.) Kadınlar Dünyası 51.-100. Sayılar (Yeni Harflerle) (1913-1921). Kadın Eserleri Kütüphanesi ve Bilgi Merkezi Vakfı, İstanbul 2009; Birsen Talay Keşoğlu ve Mustafa Keşoğlu, (eds.) Türk Kadını 1918/1919 Yeni Harflerle. Kadın Eserleri Kütüphanesi ve Bilgi Merkezi Vakfı, İstanbul 2010; Safiye Kıranlar, Savaş Yıllarında Türkiye'de Sosyal Yardım Faaliyetleri (1914-1923), (İstanbul Üniversitesi Sosyal Bilimler Enstitüsü, Yayımlanmamış Doktora Tezi), İstanbul 2005; Erol Köroğlu, Türk Edebiyatı ve Birinci Dünya Savaşı, 1914-1918: Propagandadan Milli Kimlik İnşasına, İletişim Yayınları, İstanbul 2004; Meral Altındal, Osmanlıda Kadın, Altın Kitaplar Yayınevi, İstanbul 1994; Fatma Müge Göçek, "From Empire to Nation: Images of Women and War in Ottoman Political Cartoons, 1908-1923", Borderlines: Genders and Identities in War and Peace 1870-1930, Ed. Billie Melman, Routledge, New York 1998, s. 47-72; Fatmagül Berktay, "Osmanlı'dan Cumhuriyet'e Feminizm", Tarihin Cinsiyeti, 2. Basım, Metis Yayınları, İstanbul 2006, s. 88-111; Fatmagül Berktay, "Tanzimat'tan Cumhuriyet'e Feminizm", Cumhuriyet'e Devreden Düşünce Mirası: Tanzimat ve Meşrutiyet'in Birikimi, Eds. Tanıl Bora ve Murat Gültekin, İletişim Yayınları, İstanbul 2001, s. 348-362; Aslı Davaz, Eşitsiz Kız Kardeşlik: Uluslararası ve Ortadoğu Kadın Hareketleri ve Türk Kadın Birliği, Türkiye İş Bankası Kültür Yayınları, İstanbul 2014; Zafer Toprak, "Osmanlı Kadınları Çalıştırma Cemiyeti: Kadın Askerler ve Milli Aile”, Tarih ve Toplum, C.8, S.51, Mart 1988, s. 34-38; Zafer Toprak, "II. Meşrutiyet Dönemi’nde Devlet, Aile ve Feminizm”, Sosyo/Kültürel Değişme Sürecinde Türk Ailesi, cilt 1, Başbakanlık Aile Araştırma Kurumu Yayınları, Ankara, 1993, s. 216-227; Zafer Toprak, "The Family, Feminism, and the State during the Young Turk Period, 1908-1918", Première Rencontre Internationale sur l'Empire Ottoman et la Turquie Moderne, Éditions ISIS, İstanbul-Paris 1991, s. 441452; Zafer Toprak, Türkiye'de Kadın Özgürlüğü ve Feminizm (1908-1935), Tarih Vakf1 Yurt Yayınları, İstanbul 2014; Leyla Kaplan, Cemiyetlerde ve Siyasi Teşkilatlarda Türk Kadını (1908-1960), AKDTYK Atatürk Araştırma Merkezi, Ankara 1998; Serpil Çakır, Osmanlı Kadın Hareketi. 3. Basım. Metis Yayınları, İstanbul 2011; Serpil Çakır, “Osmanlı'da Kadınların Mekânı, Sınırlar ve İhlaller”, Cins Cins Mekan, Haz. Ayten Alkan, Varlık Yayınları, İstanbul 2013, s. 76-101; Sarah Graham-Brown, Images of Women: The Portrayal of Women in Photography of the Middle East, 1860-1950, Quartet Books, London 1988; Zeynep Kutluata, “Geç Osmanlı ve Erken Cumhuriyet Dönemi'nde Toplumsal Cinsiyet ve Savaş: Kara Fatma(lar)", Kültür ve Siyasette Feminist Yaklaşımlar 2006-2007 Seçkisi, Ed. Derya Demirler vd. İstanbul 2008, s. 149-168; Zeynep Kutluata, "Ottoman Women and the State During World War I" (Sabancı Üniversitesi, Sosyal Bilimler Enstitüsü, Yayımlanmamış Doktora Tezi), İstanbul 2014; Serpil Sancar, Türk Modernleşmesinin Cinsiyeti: Erkekler Devlet, Kadınlar Aile Kurar, 2. Baskı, İletişim Yayınları, İstanbul 2013; Pars Tuğlacı, Osmanlı Döneminde Osmanlı Kadınları, C. 1, Cem Yayınevi, İstanbul 1984; Ayșe Gül Altınay, Vatan, Millet, Kadınlar, 5. Baskı, Ed. Ayșe Gül Altınay, İletișim Yayınları, İstanbul 2013; Ayşegül Baykan- Belma Ötüş-Baskett Nezihe Muhittin ve Türk Kadını (1931), İletişim Yayınları, İstanbul 1999;
} 
Sadece ülkemizde değil tüm dünyada kadınlar geçmişte tarih sahnesinde genel olarak arka planda yer almış ve çoğu zaman tarihin konusu bile olamamışlardır.

Virginia Woolf, 20. yüzyılın başlarında, kadınların tarihinin olmadığından yakınıordu. Kadınların kendi seslerini bulabilmeleri ve o sesin duyulmasını sağlayabilmeleri için 'kendine ait bir oda' kadar, 'kendine ait bir tarih'e [de] sahip olmaları gerekliydi. Bu olmadığı sürece, bir toplumsal grup olarak kadınların belleği de olmuyor ve varoluş çabaları, Penelope'nin dokuması gibi her gün sökülüp yeni baştan dokunmak zorunda kalıyordu. ${ }^{5}$

Gramsci'nin dediği gibi "hatırlamak, direnmektir" ve geçmişimize tam anlamıyla sahip çıkmadan kendimize gelecek inşa edebilmemiz mümkün değildir. Tarihi kadın ve erkekler beraber yaptıklarından kadınların tarih sahnesinde yer alması ve tarihte kadınların konumu üzerine yapılan araştırmaların arttırılması gerekmektedir.

\section{Savaş ve Kadın}

Tarihte savaşlar söz konusu olduğunda kadınlar sıklıkla bir araç olarak kullanılmıştır. Örneğin, Amerika Birleşik Devletleri, Afganistan'ı işgal etmeden haftalarca önce televizyon kanallarında Afganlı kadınları göstermiş "bu geri kalmış, ezilen kadınları kurtarmamız gerek" diyerek bölgeye yapılacak olan Amerikan müdahalesini meşru kılma çabası içerisine girmiştir.

1325 sayılı BM Güvenlik Konseyi Kararı, ${ }^{6}$ silahlı çatışmalarda olumsuz etkilenenlerin çoğunluğunun ve silahlı unsurlar tarafindan daha fazla hedef alınanların kadın ve çocuklar olduğunu göstermektedir. Aynı Konsey kararı, kadınların ve kız çocuklarının insan haklarına sayg1 gösterilmesini ve haklarının korunmasını sağlayacak gerekli tedbirlerin alınması gerektiğini vurgular. Silahlı çatışmaların tüm taraflarını, kadınları ve kız çocuklarını toplumsal cinsiyete dayalı şiddetten, özellikle tecavüz ve diğer cinsel istismar biçimlerinden korumaya ve özel tedbirler almaya çağırır.

1949 Cenevre Sözleşmeleri, 1977'de Cenevre Sözleşmesine eklenen protokoller, 1951 Mülteci Sözleşmesi, 1967 Mülteci Sözleşmesi ek protokolü, 1979 Kadınlara Karşı Her Türlü Ayrımcilığın Önlenmesi Sözleşmesi (CEDAW), 1999 CEDAW'a eklenen İhtiyari Protokol, 1989 BM Çocuk Haklarına Dair Sözleşme, 25 Mayıs 2000'de Çocuk Haklarına Dair Sözleşmeye eklenen iki İhtiyari Protokol, kadın ve savaş hakkında kaleme alınmış dokümanlardır. Sayfalarca maddelerden oluşan bu sözleşmeler savaş veya çatışma sırasında kadın ve kız çocuklarının erkeklerden daha fazla şiddete maruz kaldıklarını, kadın ve çocukların korunması için daha fazla çaba harcanması gerektiğini gözler önüne sermektedir. Bu sözleşmelerin varlığı aynı zamanda içlerinde yer alan ve dikkat çekilmek istenen konuların, daha önceki yıllarda gerçekleştiği anlamına da gelmektedir. Sözleşme veya protokollerin her biri ve maddeleri, yaşanan kötü deneyim ve tecrübelerin delili niteliğindedir.

Bekir Sıtkı Baykal, Milli Mücadele'de Anadolu Kadınları Müdafaa-i Vatan Cemiyeti, AKDTYK Atatürk Araştırma Merkezi, Ankara 1986; Ayşe Durakbaşa, "Cumhuriyet Döneminde Kemalist Kadın Kimliğinin Oluşumu” Tarih ve Toplum, S. 91, Mart 1988, s. 39-43; İkbal Elif Mahir Metinsoy, "Poor Ottoman Turkish Women during World War I: Women's Experiences and Politics in Everyday Life, 1914-1923", (Boğaziçi Üniversitesi, Sosyal Bilimler Enstitüsü, Yayımlanmamış Doktora Tezi), İstanbul 2011; Seda Öztürk, Birinci Dünya Savaşı Sonunda Türk Kadını ve Türk Kadını Dergisi, (Sakarya Üniversitesi, Sosyal Bilimler Enstitüsü, Yayımlanmamış Yüksek Lisans Tezi) Sakarya 2010; Fevziye Abdullah Tansel, İstiklâl Harbi'nde Mücâhit Kadınlarımız, 2. Bask1, Atatürk Kültür Merkezi Yayını, Ankara 1991; İrvin Cemil Schick, Batı'nın Cinsel Kıyısı: Başkalıkçı Söylemde Cinsellik ve Mekânsallık, Çev: Savaş Kılıç - Gamze Sarı, Tarih Vakfı Yurt Yayınları, İstanbul 2000; Yaprak Zihnioğlu, Kadınsız Inkllap: Nezihe Muhiddin, Kadınlar Halk Firkası, Kadın Birliği, Metis Yayınları, İstanbul 2003.

${ }_{6}^{5}$ Fatmagül Berktay, Tarihin Cinsiyeti, 2. Basım, Metis Yayınları, İstanbul 2006, s. 32.

6 "Kadınlar, Barış ve Güvenlik" başlıklı bu karar 31 Ekim 2000 tarihinde kabul edilmiştir. 
Savaş Bittiğinde Bitmiş Demek Değildir: Savaş Harabelerinden Konuşan Kadınlar ${ }^{7}$ başlıklı kitapta, askeri zafer geldikten sonra bile kadınların ve çocukların en çok etkilenenler olduğu vurgulanmakta, barışla beraber kadınlara karşı ev içi ve cinsel şiddetin daha da kötüleşip arttığı anlatılmaktadır. ${ }^{8}$ Cinsel saldırı yaş aralığı on iki yaşın altındaki kızlardan başlayarak altmış üç yaşına kadar değişmektedir. Yaş sınırı son İnsan Hakları İzleme Komitesi'nin raporlarına göre üç yaşa kadar düşmektedir. Hızlı kaçamayacak kadar küçük olanlar veya yaşlılar en sık saldırıya uğrayanlar arasında yer almaktadır. Bazı kadınlara kocaları ve çocuklarının önünde tecavüz edilmekte veya kadınlar ailesinin veya kocasının ölümüne tanık olmaya zorlanmaktadır. Askerlerin kamplarına götürülüp orada yemek yaptırılıp, toplu tecavüze uğramaktadırlar. Dövülen, işkenceye maruz bırakılan bu kadınlar büyük acılar çekmektedirler. Savaş bittikten yıllar sonra bile oturmakta, ayakta durmakta veya yürümekte zorluk çekmekte ve cinsel yolla bulaşan ciddi hastalıklarla mücadele etmek zorunda kalmaktadırlar. Kitap, ayrıca savaş bittikten sonra erkeklerin acılarını, gördükleri veya yaptıkları kötü şeyleri düşündüklerini belirtirken, kadınların onlara yapılanların sonuçlarına katlanmak zorunda kaldıkları gerçeğini vurgular. ${ }^{9}$

İnsan Hakları İzleme Komitesi raporlarına göre günümüzde savaş sırasında gerçekleşen cinsel taciz ve istismarın çok azı rapor edilmektedir. Kadınlar, suçu işleyenin intikam almasından, otoritenin aynı şekilde karşılık verip misilleme yapmasından, öç almasından veya kayıtsız kalmasından, içerisinde yaşadıkları toplum veya aileleri tarafından aforoz edilmekten, dışlanmaktan, sürgüne gönderilmekten ve kültürel tabuların ihlâl edilmesinin getireceği, bilinmeyen sonuçlardan korkmaktadırlar. ${ }^{10}$

\section{Birinci Dünya Savaşı ve Kadın}

Birinci Dünya Savaşı'nda, savaş ile ilgili tasarruf ve kredi tahvillerinde, posterlerde, savaş tasarruf pullarının üzerinde, kadın imajları sıklıkla kullanılmış ve belgelerde yer alan kadınlar ulusal sembol, savaşa katkı verenler, anne ve kurban olarak temsil edilmişlerdir. Amerika Birleşik Devletleri'nde savaşa katkı veren kadın imajı, ulusal sembol olan kadın imajından daha fazla kullanılmışken, anne olarak kadının tasvir edildiği posterler ülkede daha az ilgi görmüştür.

Aslında kadınların, savaşı somut olarak durdurmak için yapabilecekleri fazla bir şey yoktu. Savaşa giden erkeklerin yerine çalışmaya başladılar ve ne yazı ki bazı sanayi sektörlerinde çalışmak zorunda kaldıklarından, savaşa doğrudan katkıda bulunmuş oluyorlardl. Parlamentoda söz sahibi olmadıkları için siyasal mekanizmalarda savaşla ilgili kararlara katılamadılar. ${ }^{11}$

Birinci Dünya Savaşı sonunda dünya genelinde kadının toplumsal konumunda değişiklik meydana gelmiştir. Savaş sırasında kadınların silah fabrikalarında ve savaş hizmetinde çalışması, savaş süresince ülkelerine katkıları, savaş sona erdiğinde onların yıllardır süre gelen oy verme ve seçilme arzularını arttırmış, kadınlar toplumun erkekle eşit haklara sahip bir üyesi olma yolunda önemli adımlar atmışlardır.

\footnotetext{
${ }^{7}$ Ann Jones, War is not over When it is over: Women Speak out from the Ruins of War, Metropolitan Books, New York 2010.

${ }^{8}$ Age, s. 7.

${ }^{9}$ Age, s. 19-20.

${ }^{10}$ Age, s. 19.

${ }^{11}$ Davaz, Eşitsiz Kız Kardeşlik, s. 102.
} 


\section{Birinci Dünya Savaşı Öncesinde Türk Kadını: II. Meşrutiyet ve Erkek Başkaldırışı}

Birinci Dünya Savaşı y1lları öncesinde batılılaşma ve modernleşme çabasındaki İttihat ve Terakki Cemiyeti, kadın değişirse toplumun değişebileceğine inanmış ve yeni bir Türk kadını yaratma gayretine girmiştir. Kadın ve erkeğin eşit olduğu, kadının özgürlüklerinin genişletildiği çağdaş bir toplum inşa etmeyi arzulamıştır. II. Abdülhamit'in baskıcı iktidarına karşı bir araya gelen Jön Türklerin oluşturduğu İttihatçılar, Abdülhamit'i devirmek ve Meşrutiyet'i ilan etmek istemişlerdir. ${ }^{12}$

II. Meşrutiyet öncesinde kadınların özgürleşmesi konusu "Batılılaşmadan başka bir şey olmayan modernlikle özdeşleştirilmiş ve onunla karıştırılmıştır". ${ }^{13}$ Aslında bu dönemde Türk erkek aydınlarının zihnine kadın özgürlüklerinin genişletilmesi konusunun gelmesi, kendi özgürlüklerinin peşinde olmaları sebebiyledir.

[Erkekler] geleneksel Osmanl hayatının baskıcı kurallarından kurtulmak, özgür olmak derdindedirler...Adını koymak gerekirse bu tam anlamıyla, ailedeki Osmanlı ataerkil düzenine erkek başkaldırısının bir biçimidir ve böyle bir başkaldırı ancak söz konusu erkekler kendi kuşaklarından kadınları da peşleri sıra sürükleyebilirlerse başarılı olabilir....

[Erkekler] artık yaşlı kadın akrabaları tarafindan ayarlanan ve denetlenen görücü usulü evlilik istememektedirler; romantik ilişki ve aşk özlemi çekmektedirler; karşıllklı düşünce alışverişinde bulunabilecekleri eğitilmiş zevceler istemektedirler. İki cinsin rezalet ya da dedikodu korkusu olmadan bir arada bulunabilecekleri bir sosyal yaşam özlemektedirler, klsacasl, geleneksel Osmanl hayatının baskicı kurallarından kurtulmak, özgür olmak derdindedirler. ${ }^{14}$

$\mathrm{Bu}$ sebeple, Birinci Dünya Savaşı öncesinde II. Meşrutiyet'in ilanının hemen başında kadınların durumları ile ilgili olarak "kadın Osmanlı'da süregelen geleneksel yaşam biçimini bırakmalı, toplumsallaşmalı, özgürlüklerini genişletmelidir" görüşü ortaya çıkmıştır. ${ }^{15} \mathrm{Bu}$ yüzden, "Türkiye'de Batı'dakine benzer bir feminist hareket II. Meşrutiyet yıllarında gün 1şı̆̆ına çıkar [ve] Osmanlı kadınları Batıdaki feminist akıma benzer bir hareketi II. Meşrutiyet'in özgürlük ortamında başlatırlar". ${ }^{16}$

\section{Birinci Dünya Savaşı Öncesinde Türk Kadını: Kadınlar Dünyası Dergisi}

Şarkiyatçı veya milliyetçi söylemlerin Türk kadını algısı üzerine örnekler vermesi açısından Kadınlar Dünyası dergisinin yazıları önemlidir. Dergi 1913-1921 tarihleri arasında yayın hayatına devam etmiş, Birinci Dünya Savaşı'nda yayınını kesmek zorunda kalmıştır. Bu duruma, derginin yazı kadrosunu oluşturan kadınların gönüllü olarak savaşta görev almak istemeleri yol açmış hatta Enver Paşa'ya telgraf çekilerek "kadınların harpte dahi erkekler gibi ifayı vazifeye hazır oldukları, emre amade oldukları" bu nedenle yayına ara verecekleri belirtilmiştir.

\footnotetext{
12 Detaylı bilgi için bkz.: Bayram Kodaman, “II. Meşrutiyet Dönemi (1908-1914)”, Türkler Külliyatı, Cilt 13, Yeni Türkiye Yayınları, Ankara 2002, s. 183-184.

${ }^{13}$ Deniz Kandiyoti, "Ataerkil Örüntüler: Türk Toplumunda Erkek Egemenliğinin Çözümlenmesine Yönelik Notlar” Cariyeler, Bacılar, Yurttaşlar: Kimlikler ve Toplumsal Dönüşümler, 2. Basım, Metis Yayınları, İstanbul 2007, s.190.

${ }^{14}$ Agm, s. 190-191.

${ }^{15}$ Toprak, “Osmanlı Kadınları”, s. 34

${ }^{16}$ Agm, s.34.
} 
16-23 Mart 1914'te Roma'da toplanan Uluslararası Kadın Kongresi'ne hiçbir Türk kadınının katılmaması ile ilgili olarak yazılan yazıda, Türk kadınının içinde bulunduğu olumsuz koşullar ve toplumdaki ikincil konumu dile getirilmiştir. Yazıda "[o] kongreye giden bir Türk kadını ne diyecek?" ${ }^{17}$ sorusundan hareket edilmiştir. "Her millete mensup kadınlar memleketlerindeki durumu anlatırlarken Türk kadını da derdini dökmeye başlayacak, Türkiye'deki kadınların halini anlatmaya başlayacak" diye başlayan yazıda Türk kadınının içerisinde bulunduğu durum şöyle tasvir edilmiştir:

Bizde klz mektebleri, erkek mekteblerinin onda biri nisbetindedir. Bizdeki kadınların yüzde doksanı hiç tahsil görmemiştir, belki okuma yazma da bilmez. Bizde kadın, köylerde hayvanla beraber çift sürer; şehirlerde erkeklere yalnız alet-i zevc ve hizmetçi olur... bizde kadın, erkeksiz yaşayamaz, bir hane bile isticar [kiralama] edemez. Bizde kadın, erkeği ölür ve maaş bırakmaz ise aç kalır; çünkü hiçbir vechile temin-i maişet [geçimini temin] etmesi imkânı yoktur. Hizmetçilik de kolay bulamaz. Zira ekser evlerde kadinlar hizmetçidir. Hariçten hizmetçi almazlar, ecnebi veya Hıristiyan evine gidip hizmetçilik edilemez. Bizde kadını kocası istediği zaman bilâsebeb tatlîk [sebepsiz yere boşama] eder. Kapı dışarı atar. Bizde kadının erkeğinden şikâyetini kimse dinlemez. Hânede erkek karısına bildiği, istediği gibi muamele eder. Bizde kadın şarkı söylemez, dans etmez, saz çalsa bile gizli çalar. Bizde kadın umûmî mahallere girebilmek şöyle dursun, hizlı lakırdı bile edemez, herkesin nazar-ı ta'yîbi [ayıplayan bakış] altında ezilir. Bizde kadın, sokaklarda, mesirelerde bile peçe altında hüviyeti meçhul koyun sürüsü gibi gezer. Bizde kadın, rast gelecek harf-endâzlı̆̆a [onur kirıcı laf atma] kol çarpmasina, nazar-ı muhakkeranesine [tahkir edici bakış] marûzdur... Bizde kadın zevciyle bir lokantada oturup yemek yiyemez. Bizde kadın, ecnebi kadınlarının gezdikleri bahçelerde gezemez...erkeğiyle beraber ziyafetlere iştirak edemez. ${ }^{18}$

$\mathrm{Bu}$ ifadelerin yazarı, tüm bunları anlattıktan sonra onu dinleyen kongre üyesinin "hiddet ve nefretle ayağa kalkacağını", "Be hey kadın! Senin burada ne işin var? Siz daha insan hukukunu istirdâd etmemişsiniz. Bizimle müzakereye nasıl geliyorsunuz?" diyeceklerini ve kendisini "kemal-i nezaketle dışarı atacaklarını" hayal etmektedir. ${ }^{19}$

\section{Birinci Dünya Savaşı ve Türk Kadını}

Osmanlı İmparatorluğu Birinci Dünya Savaşı’na girdiğinde "her iki ittifaktaki büyük güçlerle kıyaslandığında açık farkla en küçük, en yoksul ve en hazırlıksız olandı”. ${ }^{20}$ Bugün elimizde Birinci Dünya Savaşı yıllarında Türk kadını hakkında az sayıda doküman ve belge olması, dolayısıyla kadın geçmişinin bilinmemesinin nedeni, kadınların mücadeledeki rollerinin önemsiz kılınması ve küçümsenmesi sonucudur. Kadınların tarihsel özne olarak görülmemesi, mücadelelerinin "modernleşme, uluslaşma sosyalizm...ve insan hakları gibi kavramlar içinde eritilmesi" nedeniyledir. ${ }^{21}$ Tarihsel kayıtlardaki "ihmal" ve "zamanında erkeksi tarihsel hikâyelere" başkaldırmamış, kaldıramamış olmanın bir sonucudur. ${ }^{22}$ Bugün elimizde olan Birinci Dünya Savaşı'nda Türk kadını hakkındaki bilgilerin çoğu anı/ hatıra,

\footnotetext{
${ }^{17}$ Çakır, Osmanlı Kadın Hareketi, s.165.

${ }^{18}$ Age, s.165-66.

${ }^{19}$ Age, s. 166.

${ }^{20}$ Stanford J. Shaw, Birinci Dünya Savaşı 'nda Osmanlı Imparatorluğu: Savaşa Giriş, Çev: Beyza Sümer Aydaş TTK, Ankara, 2014. s. 657.

${ }^{21}$ Çakır, Osmanlı Kadın Hareketi, s. 410.

${ }^{22}$ Age, s. 410.
} 
otobiyografi, roman gibi edebi eserlerden edinilmiştir ve günümüzde de yeni ortaya çıkarılan veya basilanlarla edinilmeye devam etmektedir.

Birinci Dünya Savaşı ülkemizde kadın örgütlenmelerini arttırmış, Türk kadını "o döneme göre epey radikal ilk tepkisel eylemlerini" gerçekleştirmiştir. 1913'te Nuriye Ulviye Meylan'ın kurduğu Osmanlı Müdafaa-i Hukuk-1 Nisvan Cemiyeti'nin yayın organı Kadınlar Dünyası'nda üyelerin peçesiz fotoğrafları yayınlanmaya başlamıştır. Yayımlanan ilk fotoğrafın sahibi şair Yaşar Nezihe (Bükülmez) hanımdır. ${ }^{23}$ Osmanlı kadınlarının peçelerini atarak kendilerini basın yoluyla tanıtmaları büyük yankı uyandırırken yine bu derneğin üyelerinden Belkıs Şevket Hanım, kadınların erkeklerce yapılan her şeyi yapabileceklerini kanıtlamak amacıyla ilk defa uçağa binen ve uçan kadın olmuştur.

\section{Birinci Dünya Savaşı ile}

daha evvel savaşı görmeyen insanlar savaşın içine düşüler, evlerinde oturan kadinlar fabrikalara sevk edilerek çalışmak zorunda kaldılar. Hatta memur oldular. Kadınların girmesi düşünülmeyen işleri yaptılar ve bunlara sadece Batı medeniyetinin, Hristiyan Avrupa'nın kadınları değil, Türk imparatorluğu kadınları da dâhildir. İlk defadır ki Maliye nezaretinde kadın memur istihdam edildi, iş̧̧i taburları kuruldu. Ilk defadır ki sanayide kadın sayısı alışılmışın dışında yani dokuma ve tütünün dışında da artmaya başladı. Bunlar görülmüşşseyler değildi. ${ }^{24}$

Birinci Dünya Savaşında erkek işgücünün cepheye gidenler tarafından azalması ile kadın işgücüne ihtiyaç doğmuştur:

Seferberlik nedeniyle erkeklerin askere alınmalart ve cepheye sevk edilmeleri kadınlara istihdam alanı açar, Ticaretten fabrikalara, yol yapımından sokak temizliğine kadar birçok iş sahasında kadın çalıştırılmaya başlanır. Hatta Beyoğlu'nda, Sirkeci'de, Divanyolu'nda erkekler kadın berberlere traş olmaya başlarlar. Sabah gazetesi yar şaka "Erkeklerimiz şimdiden sakallarını kadınların ellerine vermeye başladılar" der. Savaş yıllarında Harbiye Nazırı ve Başkumandan Vekili Enver Paşa'nın girişimiyle Osmanlı Kadınları Çalıştırma Cemiyet-i İslamiyyesi kurulur. Enver Paşa'nın eşi Naciye Sultan'ın himayeleri altında gün ışı̆̆ına çıkan dernek... kadınlara istihdam alanı açmayı amaç edinir...[Dernek], payitahtı İstanbul, Üsküdar ve Beyoğlu olmak üzere ü̧̈ mıntıkaya ayırır. Her mıntıkada bir veya birkaç fabrika, o günün deyişiyle "darüssinaa" açmaya karar verir. Bu fabrikalar onar bin kişiyi istihdam edecektir. Darüssinaa'larda dantel dairesi, beyaz iş dairesi, elbise dairesi, makine ile çorap ve fanila örücülüğ̈̈ dairesi, asker çamaşırları dairesi ile kostüm, tayyör ve emsali ince işler dairesi adlarıyla değişik atölyeler yer alacaktır. Darüssinaa'larda çalışmak için kadınlardan büyük bir talep getir. İlk on dokuz gün içerisinde on bir bin kadın başvurur. Bayezid, Fatih ve Beyoğlu mintıkalarının temizliği için cemiyet üç yüz kuruş maaşla üç yüz "kadın nezafet-i fenniyye amelesi", istihdam eder. Sonradan İstanbul dişından da kadın işgücü talep edilir. Bir keresinde istek üzerine İzmir'den İstanbul'a $80 \mathrm{kadln}$ işçi gönderilir.

$B u$ arada cemiyet aracılığılla kadınlar gönüllü olarak askere alınır. Istanbul'da Birinci ordu tarafindan oluşturulan Birinci Kadın İş̧̧ Taburu... geri hizmette kadınlara

\footnotetext{
${ }^{23}$ Yaşar Nezihe hakkında detaylı bilgi için bkz: Füsun Çoban Döşkaya, “Ataerkil İdeoloji ve Yaşar Nezihe Bükülmez”, Yaşar Nezihe, Ed. Füsun Çoban Döşkaya, Çev. Harid Fedai, Dokuz Eylül Üniversitesi Fen-Edebiyat Fakültesi Yayını, Dinç Ofset, İzmir 2010, s. 819-834.

24 İlber Ortaylı, "100. Yılında Birinci Cihan Harbi", 100. Yılında Birinci Dünya Savaşı, Ed. Ümit Özdağ, Kripto Yayınevi, Ankara 2014, s. 13.
} 
istihdam alanı açar. Vakit gazetesi, "kadınlarımız nihayet şimdi askerlik hayatına dâhil olmak üzere bulunuyorlar" der... Taburun oluşturulmasında esas amaç kadınları bizzat "temin-i maişet"e alıştırmaktır. 1918'in Şubat ayında gazetelerde yer alan çağrıya göre Ordu'da işçi kadın olarak istihdam edileceklerin 18-30 yaş arası Osmanlı uyruğu ve "güçlü kuvvetli" olmasl gerekir. Ehl-i namus ve iffetten olduğu mahalli mercilerce belgelenmeli ve "kucakta taşınır çocuğu" bulunmamalıdır. ${ }^{25}$

Kadın istihdamı postane, banka, belediye hizmetleri ve hastanelerde çalışmak gibi sadece beyaz yakalı işlerle sınırlı kalmamış, Anadolu illerindeki daha geniş seferberlik çalışmalarını da kapsamıştır. 1915 yılında Ticaret Bakanlığı tarafından çıkarılan bir çeşit zorunlu istihdam ile kadın çalışanların sayısı hızla arttırılmıştır. Gönüllü kadınlar orduya destek hizmetleri vermek üzere organize olmuşlardır. ${ }^{26}$

Kadınlar her işte yer almış, yol yapımından sokak temizliğine kadar her işte çalışmışlardır. Kamusal yaşama dâhil olmuş, sorumluluk almışlardır. Savaş yılları, Türk kadınının toplumsallaşmasında hızlandırıcı rol oynamıştır. Cephe gerisinde savaşın tüm olumsuzluklarını tecrübe eden kadınlar, çözüm arayışlarına girişmiş ve güç durumda olan kadınlara yardım etmek amacıyla dernekler kurmuşlardır. Bu dernekler daha sonraki yıllarda kadınların "hak" mücadelelerinde önemli bir işleve sahip olacaktır. ${ }^{27}$

Birinci Dünya Savaşı sonunda Osmanlı yenildikten sonra, Türk kadınları açık hava toplantılarında anavatanın savunması için coşkulu konuşmalar yapmışlardır. Vatan sevgisi söz konusu olduğunda erkeklerden geri kalmayan Türk kadını, ulusal seferberlik ile Birinci Dünya Savaşı ve milli mücadele yıllarında kendini cephede, ulus kurma mücadelesi içerisinde erkek liderlerin eşit dava arkadaşları olarak bulmuştur. Bu yıllarda Türk kadını fiili olarak cepheye katılmış ve bağımsızlığın kazanılmasında zincirin halkalarından olmuştur.

Şefika Kurnaz, Cumhuriyet Öncesinde Türk Kadını isimli kitabında cephede yer alan kadınlardan bahsederken Halide Edip, "Asker Saime", "Kılavuz Hatice", "Tayyar Rahmiye", "Maraşlı bir Hanım", "Fatma Seher Hanım", "Gördesli Makbule", "Binbaşı Ayşe", "Nezahat Hanım” ve "Süreyye Sülün Hanım"ın isimlerine yer verir. ${ }^{28}$ Maraşl1, Gördesli gibi geldikleri yörenin, ilin veya bölgenin adı ile anılan bu kadınlar, Atatürk'ün Söylev demeçlerinde yine bir mekân/bölge ile ilişkilendirilerek bu sefer "Anadolu-köylü” kadını olarak karşımıza çıkarlar.

Dünyada toplumsal cinsiyet rolleri hem tarihsel hem de çeşitli bölgelerdeki toplumlara dair özgürlüklerle çeşitlilik gösterse de savaşın biçimlendirmiş olduğu ortam özellikleri o bölgeye özgü toplumsal cinsiyet rolleriyle donanır. Bu nedenle -çoğu kez- savaş ortamında kamusal mekâna çıkarılan kadınlardan beklenen girdikleri mücadelenin neferi olmaları ve sivrilmemeleridir. Bunun aksi veya emeğinin karşıllğını istemek tarihten silinmeyi getirir ve istenilen bir durum değildir.

"Cephe" söz konusu olduğunda, "karargâh" ve "siper" alt / yan mekânlar olarak karşımıza çıkarken, "cephe-gerisi”nde sıklıkla "hastane" ile "özel mekân (ev)"la karşılaşırız. Ancak bu farklı mekânların birbirine özgü göreli konumları onları var eder. Örneğin, cepheyi cephe yapan cephenin cinsiyetidir ve mekân olarak tamamen erkeklikle/erillikle özdeşleştirilir.

\footnotetext{
${ }^{25}$ Toprak, "Osmanlı Kadınları", s. 34-35.

${ }^{26}$ Deniz Kandiyoti, "End of Empire: Islam, Nationalism and Women in Turkey", Women, Islam \& the State, Ed. Deniz Kandiyoti, Temple UP, 1991, s. 30.

${ }^{27}$ Serpil Çakır, “Osmanlı Türk Kadınları Esirgeme Derneği”, Toplum ve Bilim, 45 Bahar 1989, s. 91.

${ }^{28}$ Kurnaz, Cumhuriyet Öncesinde, s. 121-124.
} 
Cephe-gerisi ise genellikle kadınların, çocuk ve yaşlıların veya engellilerin mekânı olarak tanımlanır. Savaşta kadınlar, genellikle erkeklerin teşkil ettiği ordunun hayat membalarını işleten kişiler olarak belirirler. Bu yüzden 'eril cephe'de kadın varlığı başı başına bir meydan okuma olarak da algilanabilir. Bu bağlamda bütününde eril ve erkeğe ait bir mekân olarak konumlanan cephedeki kadın varlığ yarattığı bölünmeler, cephedeki kadının psikolojisi, tanımlama ve tanımlanmalarının tartışılması son derece önemlidir.

Savaşın yıkımlarının açtığı yaralar Türk kadını yazınında "cephe ve cephe-gerisi”ne dair mekânsal bir vurguyla ve geleneksel sınırların aşılması olarak karşımıza çıkar ve bu ortamlardaki "kadın kimliği" bir yalnızlık duygusuyla kendini dışa vurur. Çoğu kez, aile hayatından kopmuş, çocuklarından vazgeçmiş, kadın kimliğini bastırmış olan bu mekânlardaki kadınların eril-cephe mekânındaki varoluş çabaları, başta erkekler tarafından hoş karşılanmaz. $\mathrm{Bu}$ ortamdaki toplumsal-kültürel pratiklerde kadının "acemi ve çocuksu tavırları" erkeklerce s1klıkla kendilerine hatırlatılır. Askeri harekat planlarında bir 'rakama' indirgenen, 'konumsuz' kadınlar daha sonraları şans getiren 'maskot' olarak adlandırılır. Cephede kadınların kendilerini konumlandırışları ise ‘bilge kadın' veya 'ana' şeklinde görülür.

Dönemin Türk kadını anlatılarında kadın, örnek eş ve örnek anne rolünden sıyrılmış olarak karşımıza çıkar. Cephe gerisinde 'savaş denilen kanlı ziyafetin mutfağı' diye adlandırdıkları hastanelerde, askeri hemşire olarak, cephede ise kadın kimliğini bastırıp adeta cinsiyetsiz bir kimlikle savaş oyunu oynayan erkekleri seyreden ve onlardan üst konumda olan kişiler olarak belirirler.

\section{Şarkiyatçı Söylem ve Türk Kadını İmgeleri}

Türkiye "tarihsel anlamda hiçbir zaman sömürge olmamıştır". Bu yüzden "doğrudan Batı sömürgesi olmuş Müslüman ülkelerde kadın haklarına karşı gösterilen tepkisel tavırlar aynı şiddette [ülkemizde] görülmemiş" ${ }^{29}$ ve şarkiyatçıların Türk kadını hakkındaki söylemleri ve söylemlerinin geçirdiği dönüşümler diğer yerlerde olduğu gibi "Müslüman kadınların kaderinin hamiliğini yapan sömürgecilere verilmiş bir taviz olarak" ${ }^{\prime 30}$ algılanmamıştır.

Şarkiyatçı söylemde "ben" ve "öteki" kavramları ayrılmaz bir biçimde "bura" ve "ora" kavramlarına bağlıdır. ${ }^{31}$ Şarkiyatçı söylemde kadın deyince akla harem, harem deyince dört duvar ve penceredeki kafes gelir. $\mathrm{Bu}$ söylem, harem kadınlarını "bireyselleşememiş çoğunluklar olarak" sunma" eğilimindedir ve onların "cinsel arzularına dair aşırı abartılı fikirlere" yer vererek harem kadınını "fettan" ve "entrikacı" kadın olarak gösterir. ${ }^{32}$

Şarkiyatçıların "harem duvarlarının ve peçenin şeffaflaştırılmasına dayanan Müslüman kadınların erotikleşmiş betimlemeleri için bu özellik uygun bir imgedir... Batı'nın cinsel 'her şeyi görebilirliği" [panopticism] Şark üzerinde iktidar kurmak, röntgencilik aracılığıyla sahip olmak, soyarak boyun eğdirmektir". ${ }^{33}$ Kadınlığın durumu geri kalmışlığın belirtisidir. Doğulu kadının acı kaderi barbarlık ve gerilik işareti olarak gösterilmektedir. Anlatıların genelinde kendi medeniyetlerini üstün tutarak cinsel açıdan sömürülen, metalaştırılmış, Batılı kadınla kıyaslanan Müslüman kadın vardır ve Şarkiyatçı tasvirlerde kadın peçelidir.

\footnotetext{
${ }^{29}$ Kandiyoti, Cariyeler, s. 76.

${ }^{30}$ Cynthia Nelson - Virginia Olesen, "Veil of Illusion: A Critique of the Concept of Equality in Western Feminist Thought", Catalyst 10-11 (Yaz 1977), s. 32 den aktaran Kandiyoti, Cariyeler, s. 76.

${ }^{31}$ İrvin Cemil Shick, Batı'nın Cinsel Kıyısı: Başkalıkçı Söylemde Cinsellik ve Mekânsallık, Çev. Savaş KılıçGamze Sarı, Tarih Vakfı Yurt Yayınları, İstanbul 2000, s. 11.

${ }^{32}$ Age, s.13.

${ }^{33}$ Age, s.13.
} 


\section{Milliyetçi Söylem ve Türk Kadını İmgeleri}

Milliyetçi söylem, şarkiyatçı söylemi "tersine çevirir"....[burada kadın] "açık, atletizm yarışmalarında yer alan, kitleler önünde konuşabilen, gelişmiş teknolojiyi kullanabilen" ${ }^{34}$ biridir. "[B]u modernlik imgeleri, değişen toplumsal cinsiyet ilişkileri üzerine bir yorumdan ziyade, 'yeni ulusun dinamizminin simgesel imaları[dırlar]". ${ }^{35}$

Milliyetçi söylemde kadın sıklıkla annelik üzerinden dillendirilir ve "vatan, korunacak bir kadın olarak temsil edilir". Bu söylem içerisinde anneler 'fedakâr anne', 'sadık eş' ayrıca 'ulusun anneleri' olma yükünü de taşırlar. "Ulusun talepleri bu yüzden tıpkı soy, aşiret ya da akrabalarla ilgili temel sadakat bağları kadar zorlayıcı olabilir; fark, bu tür taleplerin tek tek erkekler tarafından değil, devlet tarafından ve devletin yasal yönetim aygıtınca dayatılması[dır]. ${ }^{36}$ "Milliyetçiliğin dili, grup kimliğinin simgesel hazinesi olarak kadınlara özel bir yer ayırır [ve] amacını insanın 'doğal olarak' bağlı olduğu bir şeyi ifade etmek üzere, ya akrabalık (anavatan, patria) ya da yuva/yurt (heimat) terimlerini kullanarak tanımlar". ${ }^{37}$

Bir görüşe göre milliyetçi söylem halk egemenliğine yönelik milliyetçi özlemler kadınların lehine gelişen yurttaşlık hakları içinde bir talebe yol açar. Kadınların yurttaş olarak ortaya çıkmaları, kadınları etnik ve dinsel cemaatlerin geleneklerinin sınırları içinde tutan kurum ve alışkanlıkların değişimi demektir. Bir diğer görüşe göre milliyetçi söylem, "kadınları araç olarak kullanıp onları işgücünde, hatta cephede ihtiyaç olduğunda harekete geçiren, ancak ulusal tehlike ortadan kalkınca ev içinde ya da kamusal alanda ikinci sınıf roller veren...bir kandirmaca" ${ }^{38}$ dan ibarettir.

Her iki görüşün de ortak noktası, kadınların modern "ulusluk" kavramına dâhil edilmeleri ve vatandaş olarak temsil edilmelerinin, bir biçimde erkeklerinkinden farklı bir yol izlemiş olduğudur. Peki, ama kadınlar milliyetçi projelere hem etkin olarak katılıp hem de bu "projelerin rehineleri" ${ }^{39}$ haline nasıl gelmiştir? "Milliyetçi söylemin, üzerinde hatırı sayılı bir mutabakat oluşmuş bir özelliği, iki ters yöne bakma niteliğidir. [Çünkü milliyetçi söylem] kendisini hem yeni kimlikler lehine geleneksel bağlantıları dönüştürüp eritecek modern bir proje, hem de müşterek toplumsal geçmişin derinliklerinden gelen saf kültürel değerlerin dirilmesi olarak sunar". ${ }^{40}$

Milliyetçi söylemde kullanılan kadın imgelerinden 'Toplumsal geriliğin kurbanları', 'Modernliğin timsalleri', 'Kültürel safiyetin seçkin taşıyıcıları', 'Eşit yurttaşlar olarak durumları', Birinci Dünya Savaşı sırasında kullanılan Türk kadını imgeleridir.

\section{Milliyetçi Söylemin Katkıları}

Türkiye'de kadın hareketi modernleşme, milliyetçilik gibi akımların etkisiyle ortaya çıkmıştır. ${ }^{41}$ Milliyetçi görüşler, kadınların "haklarını ifade etmelerinde meşrulaştırıcı bir işlev görmüştür". Bu söylem içerisinde, kadının "nesil yetiştiriciliğindeki rolü yüzünden... içinde bulunduğu durum[un] iyileştirilmesi" vurgusu üzerinde durulmuş, "milli ailenin oluşturulması

\footnotetext{
${ }^{34}$ Kandiyoti, Cariyeler, s. 168.

${ }^{35}$ Graham-Brown, Images of Women, s. 220'den aktaran Kandiyoti, Cariyeler, s. 168.

${ }^{36}$ Kandiyoti, Cariyeler, s. 163.

${ }^{37}$ Age, s. 172.

${ }^{38}$ Age, s. 162-163.

${ }^{39}$ Kandiyoti'ye göre Cumhuriyet döneminde kadınlar, etkin olarak katıldıkları bir projenin rehineleri haline gelmiş̧lerdir.

${ }^{40}$ Kandiyoti, Cariyeler, s. 165-166.

${ }^{41}$ Fatmagül Berktay'da "Cumhuriyet'in kurucu ideolojisi olan ulusçuluk ile 'Türk Feminizmi'nin el ele gittiğini”" vurgular. Bkz.;Tarihin Cinsiyeti, s. 97.
} 
ve toplumun modernleştirilmesi[nin] ancak kadının yaşamının değişmesi" ile sağlanabileceği aktarılmıştır. $^{42}$

Kadınlara erkekler kadar hak tanınmaması konusunda ileri sürülen bahanelere, milliyetçi görüşler kullanılarak cevap verilmiștir. Vatandaşliğın askerlik yapanın hakkı olduğu, kadinların ise savaşta fiziksel durumları gereği erkeklerle eş tutulamayacakları bahanesine, kadınlar "Vatan isterse, kadın asker de olur" cevabiyla karşı durmuş, meramlarını ayrıntılı olarak dile getirmişlerdir. [Bu söylem içerisinde] erkeklerden önce kadınların hakları verilmelidir. Çünkü kadın yalnız beşeriyet validesi değil, medeniyetin anası ve temelidir. Çocuğa ilk terbiyeyi veren [dir]. ${ }^{4}$

Yine bu söylem içerisinde "Osmanlı aydınlarının 'Bu devlet nasıl kurtulabilir?' sorusuna 'Ancak kadınlığın yükseltilmesiyle' yanıtı verilmiş, kadının kurtuluşu ile toplumun kurtuluşu arasındaki paralelliğe dikkat çekilmiş[tir]". ${ }^{44}$

Erkekler kadınları iyi anne, iyi eş olarak değerlendirip onların bu özelliklerini mutlaklaştıracak girişimlere gidip, düzenlemelerde bulunmuşlardır. Ama erkeklerin kendi çıkarları doğrultusunda gerçekleştirdikleri çabalar sonuçta kadının toplumsallaşmasina yarayarak onun sadece anne ve ev kadını olma zincirinin kırılmasına yol açmıştır. Çünkü "iyi" olmak için eğitim şarttır. Eğitim de farklı kimlikler istemini gündeme getirir bir süre sonra... ${ }^{45}$

Ayrıca yine milliyetçi söylem "kadınların durumunun ve ikincil konumlarını

meşrulaştıran dinsel öğretilerin sorgulanması için önemli bir kavramsal alan aç[mıştır]". ${ }^{46}$

\section{Milliyetçi Söylemin Olumsuz Yanları}

İrvin Cemil Schick milliyetçi söylemin olumsuz yanlarını şöyle özetler: "[P]eçesiz bir kadının fotoğrafı bir traktör, sanayi kompleksi ya da yeni bir demiryolundan farklı değildi. Erkeklerin başarılarının bir örneğini daha simgeliyordu yalnızca. Bu imgelerde kadınlar yine, erkekler tarafından erkekler için yürütülen siyasal söylemin hizmetinde birer nesneye indirgendiler". ${ }^{47}$

Yine de kadınların milliyetçilik içindeki payları, öne sürülenden daha karmaşıtır. Milliyetçi hareketler bir yandan kadınları "ulusal" aktörler; anneler, eğitimciler, işçiler, hatta savaşçılar olarak toplum hayatına daha fazla katılmaya davet ederler. Öte yandan kültürel olarak kabul edilebilir kadın davranışlarının sınırlarını tayin eder ve kadınları kendi çıkarlarını milliyetçi söylem tarafından belirlenen terimler çerçevesinde ifade etmeye zorlarlar. ${ }^{48}$

Örneğin, "Halide Edip'in romanlarındaki milliyetçi kadın kahraman tipi, kadın cinselliğinin artık kapatılma yoluyla olmasa bile bastırılma yoluyla denetim altında tutulduğuna ve kadının kamu alanında ancak cinsiyetsiz bir yoldaş olarak kabul edilebileceğine işaret ed[er]". ${ }^{49}$ Ulusal özgürlük için verilen savaşımın ilk ağızdan olan nadir anlatılarından biri, Halide Edip'in anılarının ikinci cildi olan Türkün Ateşle Imtihanı adlı eserinde bulunabilir.

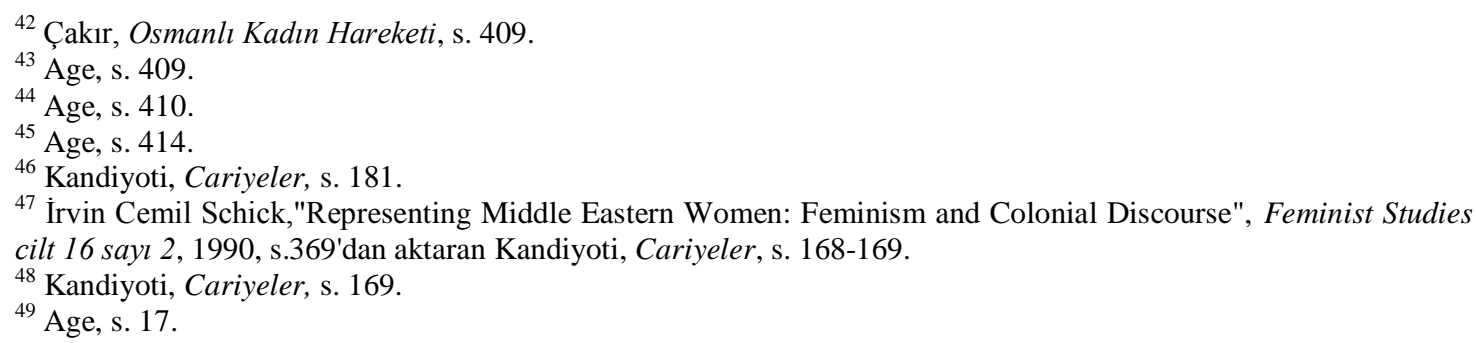


"Bir kadın evvela Osmanlı, bir vatanperverdir... Vatanın hukuku kadınlık hukukundan bin kat mühim ve muhteremdir" ${ }^{50}$ alıntısından görüldüğü üzere Halide Edip Adıvar'ın "milliyetçi kadın kahraman tasviri" milliyetçi söylem ile belli bir derecede örtüşmektedir.

Halide Edip'in "ilk romanlarından biri olan Yeni Turan'da kadın kahraman "Kaya" milliyetçi kadının prototipidir...[Burada] Yeni Turan kadını, ahlaki ve toplumsal dönüşüm içindeki bir insan [olarak anlatılır]". ${ }^{51}$ "Kadınların et durumundan, bir makineden, erkeklerin temizlikçisi ve ağır işçisinden, çocukların ve tüm milletin annesine ve hepsinin öğretmenine dönüşümünü gerçekleştiren biri olarak tasvir edilir". ${ }^{52}$

Kaya hareketli ve etkindir, mücadele içinde erkek yoldaşlarlyla omuz omuzadır. Ama iffetine diyecek yoktur....Giyinme tarzı tam olarak İslami değildir, son derece sadedir ve tavırları haşinlik derecesinde ciddidir. Ne görünüşünde ne de düşüncelerinde Batıcilı̆̆n hiçbir izi yoktur; tersine, özgün Türk/İslam sentezine dönüşü temsil eder...[mavi gözlerindeki bakışlarında] erkek ya da kadın herhangi birini ya da cinselliği hatırlatan hiçbir şey yoktur. ${ }^{53}$

Bu kadın temsilleri Adıvar'ın romanlarında sürekli olarak tekrarlanır. Handan isimli romanında, romana ismini veren Handan'ın "cinsiyetini kimse pek düşünmez, erkek gibi kızdır" $^{\text {54 }}$ diyerek tasvir eder. Bir görüşe göre, Adıvar'ın romanları Cumhuriyet Türkiyesi'nde kadınların kamusal hayata hangi koşullarda kabul edilebileceklerini ifade eden bir mecazdır ve ancak cinsiyetsiz ve kadınlıklarından sıyrılmış olarak kabulleri mümkündür. ${ }^{55}$ Dolayısıyla milliyetçi söylemde kadının birinci görevi aydın anne olmak ve çocuklarını yetiştirmektir.

Gerileme ve çöküş döneminde Osmanlı devlet yöneticilerinde var olan Avrupa'nın rızasını kazanarak ayakta durulabileceğine inanılan hastalık, Birinci Dünya Savaşı'nın hemen öncesinde Osmanlı aydınında da vardı. Batılılaşma ve Batılı standartların kullanılması ile Avrupa'da Türklere yönelik olan olumsuz tavırların aşılabileceği düşünülüyordu.

Şarkiyatçı söylemi içselleştirmiş olan bir Türk aydını kadının, Birinci Dünya Savaşı'nın hemen öncesindeki (1913) şu sözleri bunun güzel bir kanıtıdır:

Bizde kadınlık, siyah bir kefen içindedir. Bizim kadınlarımız bir Fransız edibinin dediği gibi 'şekl-i gayb-i mevcud'dan [şekli kaybolmuş bir varlik] ibarettir. Bizde kadınlar dünyanın bütün kadınlarl, bütün insanlart gibi yaşayıp ölmezler; sürüklendikleri... [sürünülerek geçirilen hayat] içinde ölü gibi yaşamaya mahkûmdurlar. Ben aksi ve yeknesak çarşaflarımızla kendimizi Şark'a aid bir tablonun kenarına sikıştırılmış bir 'siluete' ... [benzetiyorum]. Simsiyah bir gölge...ISste bizde kadının kısaca tarifi bundan ibarettir. ${ }^{56}$

$\mathrm{Bu}$ alıntıda Nesibe Ferda Türk kadınını şarkiyatçı anlatımlarda olduğu gibi hareketsiz, pasif, hatta ölü bir biçimde, şekilsiz bir varlık olarak betimler. Şarkiyatçı ressamların

\footnotetext{
${ }^{50}$ İnci Enginün, Halide Edip Adıvar'ın Eserlerinde Doğu ve Batı meselesi, İstanbul Üniversitesi Edebiyat Fakültesi Matbaas1, İstanbul 1978, s. 403'den aktaran Ayşegül Yaraman, Resmi Tarihten Kadın Tarihine: Elinin Hamuruyla Özgürlük, Bağlam Yayınları, İstanbul 2001, s. 55; Fatmagül Berktay, “Osmanl1-Türk Modernleşmesinin Etkin ve Küskün Öznesi Kadınlara Bir Örnek: Halide Edip Adıvar”, II. Meşrutiyeti Yeniden Düşünmek, Der. Ferdan Ergut, Tarih Vakfi Yurt Yayınları, İstanbul 2010, s. 28-37.

${ }^{51}$ Kandiyoti, Cariyeler, s.159.

${ }^{52}$ Halide Edib Adıvar, Yeni Turan, Atlas Kitabevi, İstanbul 1982 s. 28.

${ }^{53}$ Kandiyoti, Cariyeler, s. 159.

${ }^{54}$ Halide Edib Adıvar, Handan, [1912], Atlas Kitabevi, İstanbul 1981 s. 54.

${ }^{55}$ Bu görüş hakkında detaylı bilgiye Nazan Aksoy'un Kurgulanmış Benlikler isimli kitabından ulaşılabilir.

${ }^{56}$ Nesibe Ferda, "Bizde Kadın", Kadınlar Dünyası, 24 Ağustos (1329) (1913), no: 106, s. 14, den aktaran Çakır, Osmanlı Kadin Hareketi, s. 165.
} 
resimlerindeki kenarlara sıkıştırılmış siyah tenli köleler ile kendini özdeşleştirir ve şarkiyatçıların dilini ne kadar özümsediğini kadını bir "gölge" olarak niteleyerek gösterir. ${ }^{57}$ Tıpkı Oryantalist ressamların resimlerinde adeta şeffaf olan Çerkez güzelinin etrafında yer alan ve teninin rengi koyulaştıkça tablonun silikleşen ve kenarına atılan köle kadınlar örneğinde olduğu gibi kendisini konumlandırır.

\section{Sonuç}

Osmanlı aydınının Batılılaşma hayranlığı, bu durumu içselleştirmesi ve şarkiyatçı söylemi Birinci Dünya Savaşı sonunda tümüyle yıkılır ve yerini milliyetçi söyleme bırakır. Bu dönemde, Türk kadınının temsil ve tasvirinde, Türk kadınının haklarına vurgu yapılarak kadınların kendi haklarının neler olduğunu bilmedikleri, hatta haklarının farkında bile olmadıkları ifade edilmeye başlanır. Mükerrem Belkıs'ın "Kadınların Hayata Karışmasının Sebepleri" başlıklı 1918 tarihli yazısında aktardığı gibi artık "kadın hayata kavuşacak...bir erkeğin olduğu gibi bir aile kadını olabilmekle beraber, bir işçi, bir memur, bir mühendis, bir doktor, bir mebus, bir nazır olabilecektir". ${ }^{58} 1924$ yıllarına gelindiğinde artık milliyetçi söylemde "her meslekte erkeklerle...müsabakalara girişebilen...en kibar en nazik kadınlar[1n] bile hayata atılmaya hazırlan[dığı], her şeyi öğrenmek is[teyen]...kendi iradesine hakim [olan ve] aileye, cemiyete, insaniyete karşı yalnız bir muhabbet değil...aynı zamanda bir mesuliyet besleyen" kadınlar vardır. Sonuç olarak şarkiyatçı söylemin öne çıkardığı "Batılılaşmış kadın imgesi" cinsellik, iffetsizlik, üst sınıfa ait olma, kent soylu, hıyanet ve yozlaşma içerisinde olan kadın olarak anlatılırken milliyetçi söylem içerisinde yabancı etkilerinden arınmış, vatansever olan, yalnızca iffetli değil, açıkça cinsiyetsiz olarak tarif edilen kadın vardır. Kadınların özgürleşmesini ve peçeden çıkmalarını gerçekleştiren bu anlatılar, aynı zamanda "cinselliği bastırma peçesini" ${ }^{59}$ getirmiştir.

\section{Kaynakça}

ADIVAR, Halide Edib, Yeni Turan, Atlas Kitabevi, İstanbul 1982.

ADIVAR, Halide Edib, Handan, [1912] Atlas Kitabevi, İstanbul 1981.

ADIVAR, Halide Edib, Türk'ün Ateşle İmtihanı: İstiklal Savaşı Hatıraları, [1962] Can Yayınları, İstanbul 2007.

AKSOY, Nazan, Kurgulanmış Benlikler: Otobiyografi, Kadın, Cumhuriyet, İletişim Yayınları, İstanbul 2009.

ALTINAY, Ayşe Gül, Vatan, Millet, Kadınlar, 5. Baskı, Ed. Ayşe Gül Altınay, İletişim Yayınları, İstanbul 2013.

ALTINDAL, Meral. Osmanlıda Kadın, Altın Kitaplar Yayınevi, İstanbul 1994.

BAYKAN, Ayşegül ve Belma Ötüş-Baskett Nezihe Muhittin ve Türk Kadını (1931), İletişim Yayınları, İstanbul 1999.

BAYKAL, Bekir Sitk1, Milli Mücadele'de Anadolu Kadınları Müdafaa-i Vatan Cemiyeti, AKDTYK Atatürk Araştırma Merkezi, Ankara 1986.

\footnotetext{
${ }^{57}$ Detaylı bilgi için bkz.: Füsun Çoban Döşkaya, "Harem Resimlerinde Kadının Temsili: Harem: Peçenin Ardındaki Dünya”, Akşit Göktürk'ü Anma Toplantısı: Yazında Sanat ve Sanatçı, İstanbul, 2007. s. 67-77.

${ }^{58}$ Mükerrem Belkıs, Beşiktaş, "Kadınların Hayata Karışmasının Sebepleri", Kadınlar Dünyası, 9 Mart 1918, No. 164, s.3-4'den aktaran Çakır, Osmanlı Kadın Hareketi, s. 179

${ }^{59}$ Kandiyoti, Cariyeler, s. 161.
} 
BERKTAY, Fatmagül, "Osmanl1-Türk Modernleşmesinin Etkin ve Küskün Öznesi Kadınlara Bir Örnek: Halide Edip Adıvar”, II. Meşrutiyeti Yeniden Düşünmek, Der. Ferdan Ergut, Tarih Vakfi Yurt Yayınları, İstanbul 2010, s. 28-37.

BERKTAY, Fatmagül, Tarihin Cinsiyeti, 2. Basım, Metis Yayınlanı, İstanbul 2006.

BERKTAY, Fatmagül. "Tanzimat'tan Cumhuriyet'e Feminizm," Cumhuriyet'e Devreden Düşünce Mirası: Tanzimat ve Meşrutiyet'in Birikimi, Eds. Tanıl Bora ve Murat Gültekin, İletişim Yayınları, İstanbul 2001, s. 348-362.

BERKTAY, Fatmagül, “Osmanlı'dan Cumhuriyet'e Feminizm”, Tarihin Cinsiyeti, 2. Basım, Metis Yayınları, İstanbul 2006, s. 88-111.

BEŞIKTAŞ, Mükerrem Belkıs, "Kadınların Hayata Karışmasının Sebepleri”, 9 Mart 1918, No: 164, s. 3-4.

ÇAKIR, Serpil, Osmanlı Kadın Hareketi. 3. Basım. Metis Yayınları, İstanbul 2011.

ÇAKIR, Serpil, “Osmanlı'da Kadınların Mekânı, Sınırlar ve İhlaller”, Cins Cins Mekan, Haz. Ayten Alkan, Varlık Yayınları, İstanbul 2013, s. 76-101.

ÇAKIR, Serpil, “Osmanlı Türk Kadınları Esirgeme Derneği”, Toplum ve Bilim, 45, Bahar 1989, s. 91-97.

ÇOBAN DÖŞKAYA, Füsun, "Ataerkil İdeoloji ve Yaşar Nezihe Bükülmez”, Yaşar Nezihe, Ed. Füsun Çoban Döşkaya, Çev. Harid Fedai, Dokuz Eylül Üniversitesi Fen-Edebiyat Fakültesi Yayını, Dinç ofset, İzmir 2010, s. 819-834.

ÇOBAN DÖŞKAYA, Füsun, "Harem Resimlerinde Kadının Temsili: Harem Peçenin Ardındaki Dünya", Akşit Göktürk'ü Anma Toplantısı: Yazında Sanat ve Sanatçı, İstanbul, 2007. s. 67-77.

DAVAZ, Aslı, Eşitsiz Kız Kardeşlik: Uluslararası ve Ortadoğu Kadın Hareketleri ve Türk Kadın Birliği, Türkiye İş Bankası Kültür Yayınları, İstanbul 2014.

DEMIRCIOĞLU, Tülay Gençtürk ve Fatma Büyükkarcı Yılmaz (Eds.) Kadınlar Dünyası 51.-100. Sayllar (Yeni Harflerle) (1913-1921). Kadın Eserleri Kütüphanesi ve Bilgi Merkezi Vakfi, İstanbul 2009.

DURAKBAŞA, Ayșe, Halide Edib: Türk Modernleşmesi ve Feminizm, İletişim Yayınları, İstanbul 2007.

DURAKBAŞA, Ayşe, "Cumhuriyet Döneminde Kemalist Kadın Kimliğinin Oluşumu" Tarih ve Toplum, S. 91, Mart 1988, s. 39-43.

ENGINNÜN, İnci, Halide Edip Adıvar'ın Eserlerinde Doğu ve Batı Meselesi, İstanbul Üniversitesi Edebiyat Fakültesi Matbaası, İstanbul 1978.

FERDA, Nesibe, "Bizde Kadın”, Kadınlar Dünyası, 24 Ağustos (1329) (1913), No:106, s. 14.

GÖÇEK, Fatma Müge. "From Empire to Nation: Images of Women and War in Ottoman Political Cartoons, 1908-1923", Borderlines: Genders and Identities in War and Peace 1870-1930, Ed. Billie Melman, Routledge, New York 1998, s. 47-72.

GRAHAM-BROWN, Sarah, Images of Women: The Portrayal of Women in Photography of the Middle East, 1860-1950, Quartet Books, London 1988. 
JONES, Ann, War is not over When it is over: Women speak out from the ruins of War, Metropolitan Books, New York 2010.

KANDIYOTI, Deniz, "Ataerkil Örüntüler: Türk Toplumunda Erkek Egemenliğinin Çözümlenmesine Yönelik Notlar", Cariyeler, Bacılar, Yurttaşlar: Kimlikler ve Toplumsal Dönüşümler, 2. Basım, Metis Yayınları, İstanbul 2007 s. 185-197.

KANDIYOTI, Deniz, Cariyeler, Bacılar, Yurttaşlar: Kimlikler ve Toplumsal Dönüşümler. 2.Basım, Metis Yayınları, İstanbul 2007.

KANDIYOTI, Deniz, "End of Empire: Islam, Nationalism and Women in Turkey", Women, Islam \& the State, Ed. Deniz Kandiyoti, Temple UP, Philadelphia 1991, s. 22-47.

KAPLAN, Leyla, Cemiyetlerde ve Siyasi Teşkilatlarda Türk Kadını (1908-1960), AKDTYK Atatürk Araştırma Merkezi, Ankara 1998.

KEŞOĞLU, Birsen Talay ve Mustafa Keşoğlu, (Eds.) Türk Kadını 1918/1919 Yeni Harflerle. Kadın Eserleri Kütüphanesi ve Bilgi Merkezi Vakfı, İstanbul 2010.

KIRANLAR, Safiye, Savaş Yıllarında Türkiye'de Sosyal Yardım Faaliyetleri (19141923), (İstanbul Üniversitesi Sosyal Bilimler Enstitüsü, Yayımlanmamış Doktora Tezi), İstanbul 2005.

KODAMAN, Bayram, "II. Meşrutiyet Dönemi (1908-1914)", Türkler Külliyatı, C.13, Yeni Türkiye Yayınları, Ankara 2002.

KÖROĞLU, Erol, Türk Edebiyatı ve Birinci Dünya Savaşı, 1914-1918: Propagandadan Milli Kimlik İnşasına, İletişim Yayınları, İstanbul 2004.

KURNAZ, Şefika, Yenileşme Sürecinde Türk Kadını: 1839-1923, Ötüken Yayınları, İstanbul 2011.

KURNAZ, Şefika, Cumhuriyet Öncesinde Türk Kadını (1839-1923), 2. Baskı, T.C. Başbakanlık Aile Araştırma Kurumu Başkanlığı Yayınları, Ankara 1991.

KURNAZ, Şefika, II. Meşrutiyet Döneminde Türk Kadını, M.E.B. Yayınları, İstanbul 1996.

KUTLUATA, Zeynep, "Ottoman Women and the State During World War I" (Sabanc1 Üniversitesi, Sosyal Bilimler Enstitüsü, Yayımlanmamış Doktora Tezi), İstanbul 2014.

KUTLUATA, Zeynep, “Geç Osmanlı ve Erken Cumhuriyet Dönemi'nde Toplumsal Cinsiyet ve Savaş: Kara Fatma(lar)" Kültür ve Siyasette Feminist Yaklaşımlar 2006-2007 Seçkisi, Ed. Derya Demirler vd., İstanbul 2008, s. 149-168.

METINSOY, İkbal Elif Mahir, "Poor Ottoman Turkish Women during World War I: Women's Experiences and Politics in Everyday Life, 1914-1923", (Boğaziçi Üniversitesi, Sosyal Bilimler Enstitüsü, Yayımlanmamış Doktora Tezi), İstanbul 2011.

NELSON Cynthia - Virginia Olesen, "Veil of Illusion: A Critique of the Concept of Equality in Western Feminist Thought", Catalyst 10-11, Trent University, Peterborough, Ontario 1977, s. 8-36.

ORTAYLI, İlber, "100. Yılında Birinci Cihan Harbi", 100. Yllında Birinci Dünya Savaşı, Ed. Ümit Özdağ, Kripto Yayınevi, Ankara 2014, s. 9-16. 
ÖZTÜRK, Seda, Birinci Dünya Savaşı Sonunda Türk Kadını ve Türk Kadını Dergisi, (Sakarya Üniversitesi, Sosyal Bilimler Enstitüsü, Yayımlanmamış Yüksek Lisans Tezi) Sakarya 2010.

SANCAR, Serpil, Türk Modernleşmesinin Cinsiyeti: Erkekler Devlet, Kadınlar Aile Kurar, İletişim Yayınları, 2. Baskı, İstanbul 2013.

SCHICK, İrvin Cemil, Batı'nın Cinsel Kıyısı: Başkalıkçı Söylemde Cinsellik ve Mekânsallık, Çev: Savaş Kılıç - Gamze Sarı, Tarih Vakfı Yurt Yayınları, İstanbul 2000.

SCHICK, İrvin Cemil, "Representing Middle Eastern Women: Feminism and Colonial Discourse", Feminist Studies, C.16, S.2, 1990, s.345-380.

SHAW, Stanford J., Birinci Dünya Savaşı’nda Osmanlı Imparatorluğu: Savaşa Giriş, Çev: Beyza Sümer Aydaş, TTK, Ankara 2014.

TANSEL, Fevziye Abdullah, Ístiklâl Harbi’nde Mücâhit Kadınlarımız, 2. Bask1, Atatürk Kültür Merkezi Yayını, Ankara 1991.

TOPRAK, Zafer, "Osmanlı Kadınları Çalıştırma Cemiyeti: Kadın Askerler ve Milli Aile", Tarih ve Toplum, C.8, S.51, Mart 1988, s. 34-38.

TOPRAK, Zafer, "II. Meşrutiyet Dönemi’nde Devlet, Aile ve Feminizm”, Sosyo/Kültürel Değişme Sürecinde Türk Ailesi, cilt 1, Başbakanlık Aile Araştırma Kurumu Yayınlar1, Ankara, 1993, s. 216-227.

TOPRAK, Zafer, "The Family, Feminism, and the State during the Young Turk Period, 1908-1918," içinde Première Rencontre Internationale sur l'Empire Ottoman et la Turquie Moderne, Éditions ISIS, İstanbul-Paris 1991, s. 441-452.

TOPRAK, Zafer, Türkiye'de Kadın Özgürlüğü ve Feminizm (1908-1935), Tarih Vakfı Yurt Yayınları, İstanbul 2014.

TUĞLACI, Pars, Osmanlı Döneminde Osmanlı Kadınları, C. 1, Cem Yayınevi, İstanbul 1984.

YARAMAN, Ayşegül, Resmi Tarihten Kadın Tarihine: Elinin Hamuruyla Özgürlük, Bağlam Yayınları, İstanbul 2001.

YILMAZ, Fatma Büyükkarcı ve Tülay Gençtürk Demircioğlu (Eds.), Kadınlar Dünyası 1.-50. Sayllar (Yeni Harflerle) (1913-1921). Kadın Eserleri Kütüphanesi ve Bilgi Merkezi Vakfi, İstanbul 2009.

ZIHNIIOĞLU, Yaprak, Kadınsız İnkllap: Nezihe Muhiddin, Kadınlar Halk Fırkası, Kadın Birliği, Metis Yayınları, İstanbul 2003. 